\title{
Effectiveness of Song and Brochure Media on Increasing Adolescent Knowledge in the Prevention of Diabetes Mellitus at SMP Negeri 5 Kota Mojokerto
}

\author{
$1^{\mathrm{s}}$ Syamsiatul Faricha Fafylia \\ Departement of Public Health \\ Faculty of Sport Science, \\ Universitas Negeri Malang \\ Malang, East Java, Indonesia \\ Syamsiatulff@gmail.com
}

\author{
$2^{\text {nd }}$ Supriyadi \\ Departement of Public Health \\ Faculty of Sport Science, \\ Universitas Negeri Malang \\ Malang, East Java, Indonesia \\ Supriyadi.fik@um.ac.id
}

\author{
$3^{\text {rd }}$ Septa Katmawanti \\ Departement of Public Health \\ Faculty of Sport Science, \\ Universitas Negeri Malang \\ Malang, East Java, Indonesia \\ Septakatma@gmail.com
}

\begin{abstract}
Health is a major problem experienced by people in Indonesia. One of the many diseases suffered by the people of Indonesia and even the world is diabetes mellitus. Diabetes mellitus is a disease caused by sugar in the blood that cannot be used by the body so that the level of sugar in the blood becomes high. Diabetes mellitus is caused by several factors, one of which is overweight (obesity) and the target group at risk of obesity is adolescence. Knowledge enhancement through education and health promotion to prevent diabetes mellitus is urgently needed. The steps taken to increase this knowledge are to provide education to students of SMPN 5 Kota Mojokerto using song and brochure media because it's educational and interesting. This study aims to determine the effectiveness of song and brochure media on increasing adolescent knowledge in the prevention of diabetes mellitus. This study used a pre-experimental research design with one group pre-test post-test. Sampling with purposive sampling techniques and data analysis techniques using the Wilcoxon Matched-Pair Signed Rank Test. The results showed that there were no respondents with lower knowledge compared to before being given song and brochure media, 4 people remained, and 29 people experienced increased knowledge after being given song and brochure media. The significance value of the Wilcoxon Matched-Pair Signed Rank Test is $0,000(p<0.05)$ which means that there are significant differences in adolescent knowledge in efforts to prevent diabetes mellitus between before and after being given song and brochure media
\end{abstract}

Keywords—song media, brochure, knowledge, diabetes mellitus prevention, adolescents.

\section{INTRODUCTION}

Health is a major problem experienced by the people of the State of Indonesia. The disease that is often faced by residents of the State of Indonesia and even the world is diabetes mellitus. According to Ministry of Health of Republic of Indonesia, diabetes mellitus is a disease whose cause is due to the sugar in the blood being unable to function by the body resulting in an increase in blood sugar levels. ${ }^{1}$ The total number of cases of diabetes mellitus is getting higher every year. According to Riskesdas 2018, when compared with the case of diabetes mellitus in 2013, cases of diabetes mellitus in people aged 15 years and older based on doctor's diagnosis increased to $2 \%$. The prevalence of diabetes mellitus for all ages in
Indonesia is lower than diabetes mellitus at the age of 15 years and over, which is as much as $1.5 \% .^{2}$ East Java Province is the fifth highest contributor to diabetes mellitus cases in Indonesia with a prevalence of $2.1 \%$ in 2013 and an increase of $2.6 \%$ in 2018. ${ }^{3}$ In 2018, the second highest diabetes mellitus in East Java Province was located in Mojokerto City with a prevalence of $2.7 \%$ in 2013 and an increase of $5 \%$ in $2018 .{ }^{4}$ Mojokerto is the city with the highest increase in the incidence of diabetes mellitus by $2.3 \%$. Based on data from interviews conducted in the field of disease prevention and control (P2P) Mojokerto City Health Office, during the last two years the prevalence of diabetes mellitus in Mojokerto City experienced a very large increase of 3,301 cases in 2017 and rose to 5,387 cases in the year 2018. Furthermore, in January-September 2019, there have been 3,365 cases of diabetes mellitus recorded at the Mojokerto City Health Office.

There are several factors that cause diabetes mellitus and of these factors, being overweight (obesity) is the most important factor. There is evidence that in the prenatal period, early childhood and adolescents greatly influence the development of obesity. Most obese people have high levels of plasma free fatty acids (FFA), which can cause periphal (muscular) insulin resistance..$^{5}$ Adolescents (10-18 years) are vulnerable to nutrition because there are many supporting factors, including the need for additional nutritional intake due to an increase in physical growth, a shift in eating habits and lifestyle in adolescents, and adolescents have special nutritional needs. The existence of globalization that has developed widely is the cause of changes in something consumed by adolescents. The occurrence of being overweight that is not proportional to the height of his age is a sign that the teenager is obese. This is due to the accumulation of too much fat in body fat tissue. ${ }^{6}$

The results of Riskesdas from 2007-2018 showed a case of concern where the proportion of central obesity at the age of 15 years to adulthood increased. In 2007 the proportion of central obesity was $18.8 \%$, in 2013 the proportion of central obesity increased by $26.6 \%$ and in 2018 the proportion of central obesity reached $31 \% .^{3}$ In the period 2013-2018, the highest obesity disease in East Java Province was located in Mojokerto 
City with a prevalence of $44.18 \% .{ }^{4}$ Based on interview data that has been carried out in the field of disease prevention and control (P2P) in the Mojokerto City Health Office, it is known that the largest obesity is in the working area of the Kedundung Health Center. There are two types of obesity in the work area, namely obesity based on Body Mass Index (BMI) and central obesity (obesity based on abdominal circumference). Of the 4,854 people who performed an obesity check, there were 2,021 people included in the obesity category according to the Body Mass Index (BMI) with details of cases of obesity in 1,452 women and 560 in males and 2,438 in the central obesity category (obesity based on abdominal circumference with details of cases of obesity in women as many as 1,924 people and in men as many as 514 people.

According to the data and the results of interviews conducted in the field of non-communicable diseases (PTM) at the Kedundung Health Center, the highest obesity prevalence was found in SMP Negeri 5, Kota Mojokerto. There were 124 students who were obese with details of grade 7 being obese as many as 44 students, grade 8 being obese as many as 46 students, and grade 9 being obese as many as 34 students. This means that cases of diabetes mellitus will increase in the following year if the incidence of obesity is not treated immediately. According to Yaturu, type 2 diabetes mellitus and obesity are public health problems that cause concern throughout the world. This is very alarming because diabetes mellitus greatly affects the capacity of human resources and will affect the increase in high health costs. The increasing prevalence of diabetes mellitus is parallel to the prevalence of obesity which some experts call this dual epidemic as "diabesity". 5 Based on the results of a preliminary study that has been carried out at the Mojokerto City Health Office, there has never been any research on obesity and diabetes mellitus in the city. In addition, there has never been an intervention in the promotion of health promotion media in the city of Mojokerto related to tackling the incidence of diabetes mellitus and obesity. Mojokerto City Health Office has made several efforts to deal with diabetes mellitus, namely health history screening and Chronic Disease Management Program (Prolanis) at the Health Center and there are still no achievement targets in tackling the incidence of diabetes mellitus and obesity.

Efforts that have been made by the Ministry of Health of the Republic of Indonesia to tackle the incidence of diabetes mellitus are the establishment of 13,500 units of Integrated Development Post (Posbindu) to facilitate the reach of the population in an effort to carry out diabetes mellitus screening. The Minister of Health of the Republic of Indonesia also continues to remind all people to carry out CERDIK actions in the form of messages to improve healthy lifestyles, including routine health screening so that weight can be controlled and remain ideal and not prone to illness, routinely do blood sugar, cholesterol and blood pressure checks. ; avoiding cigarette smoke and not smoking; diligently doing sports or physical activity for at least half an hour in one day and doing it right, well, measured and regularly; go on a balanced diet by meeting healthy food intake and balanced nutrition, eating fruits and vegetables at least 5 servings every day, not consuming foods that contain lots of glucose or high carbohydrates and not consuming more than 4 tablespoons of sugar per day; get enough rest; and managing stress properly and correctly. ${ }^{2}$

Knowledge enhancement through education and health promotion to prevent diabetes mellitus is urgently needed. A study related to increasing knowledge has been carried out by Wahyuni, et al in research on the effectiveness of type 2 diabetes mellitus patient education on outpatient glycemic knowledge and control at Anwar Medika Hospital which shows that there are differences in the value of knowledge and glycemic control so that in this case education can play a role important in increasing knowledge and glycemic control. ${ }^{?}$ Widyoga, et al also strengthen the relationship between the level of knowledge of diabetes mellitus on diet and physical activity in patients with type 2 diabetes mellitus at Griya Bromo Clinic. ${ }^{8}$ The role of various parties in overcoming diabetes mellitus very needed. The government and the community must participate in the prevention of diabetes mellitus, especially in preventive and promotive efforts. As explained by the Ministry of Health of the Republic of Indonesia that medical science is currently unable to prevent type 1 diabetes mellitus. An efficient approach is needed to prevent type 2 diabetes mellitus, complexity, and premature death that cause various types of diabetes mellitus, including also strategies and spontaneous implementation in a specific community and region (work area, home, and school) that play a role in the health of the whole community, both diabetics and non-sufferers, as well as regular exercise, consumption of nutritious food, stay away from cigarettes, and monitor blood pressure and fat content. ${ }^{2}$

In an effort to promote the CERDIK action, field officers must have more interesting ideas and dare to develop other methods and be able to convey a message from the Ministry of Health of the Republic of Indonesia in the form of a message to promote a healthy lifestyle. The media for delivering CERDIK actions has been very influential on education about the prevention of diabetes mellitus early on in the target community. ${ }^{9}$ A study of the effectiveness of learning media in the form of songs to increase knowledge has been carried out by Suciana regarding the effect of using song media on the ability to write short stories in grade $X$ high school students Negeri 6 Kediri that the results of the study show that the use of song media has an effect on the ability to write short stories for grade X students of SMA Negeri 6 Kediri. ${ }^{10}$ students playing the group and stated that the song used as a balanced nutrition promotion media is more effective and efficient when compared to the use of conventional media. ${ }^{11}$

In addition, a study on the effectiveness of instructional media in the form of brochures to improve the knowledge and abilities that have been carried out by Putra regarding the effectiveness of health promotion media leaflets and brochures in hypertensive patients stated that the leaflets and brochures used by the PKRS Team at Kaliwates Jember Hospital were effective for counseling. inpatient hypertension patients. All informants decided to accept health promotion media which 
reinforced the existence of broad outline data including recipient characteristics, social system characteristics, and innovation characteristics, which tended to reinforce the adoption of innovative media promotion of health promotion leaflets and brochures by hypertensive patients. ${ }^{12}$ Stefanie also reinforced the existence of the benefits of the brochure in research on visitor responses to the Jatim Park 2 media brochure which shows that attention, interest, and desire can encourage consumers to make purchases that affect the response of visitors. This shows that the brochure information media was successfully embedded in the memories of visitors, thus giving a positive response to the services offered by Jatim Park 2. This explains that a message that is always repeated will ultimately result in the recall of the message by the consumer. ${ }^{13}$ These values indicate that the song and brochure becomes a recommendation for health education media ang good to promote the action of CERDIK in the form of messages to improve healthy lifestyles to the target community for the prevention of diabetes mellitus early on.

From this background explanation, the authors would like to carry out health promotion efforts to the community in SMP Negeri 5 Kota Mojokerto in an effort to prevent diabetes mellitus early on. The step taken to realize these goals is to provide education to teenagers or students in SMP Negeri 5 Mojokerto. This health education media is educational and appealing to adolescents so the authors hope that adolescents can find out how to prevent diabetes mellitus as early as possible. The media is an indicator of how to prevent and manage diabetes mellitus which is packaged in a song and brochure, so that teenagers are interested in receiving education related to diabetes mellitus prevention early on as a step to prevent and treat diabetes mellitus in SMP Negeri 5 Kota Mojokerto.

\section{METHODS}

\section{A. Study Design}

This study used a pre-experimental research design with a one group pre-test post-test research design. In this study, respondents will be given treatment $(\mathrm{X})$ that is given health education using song and brochure media. Before treatment, the researcher will give a pre-test to the respondent to see the level of initial knowledge about diabetes mellitus. After that, researchers will provide interventions within a certain timeframe. After being given treatment, the researcher will give a final test (post-test) to see if there is an increase in knowledge after being treated. Furthermore, the final results of the measurement will be compared between before and after the song and brochure media is given.

\section{B. Population and Sample}

The population in this study were grade 9 students of SMP Negeri 5 Mojokerto City who were obese. This study uses a purposive sampling technique using inclusion and exclusion criteria. Inclusion criteria in this study are: 1) Students who are categorized as obese, 2) Aged 15 years and above, 3) Take education in SMP Negeri 5 Mojokerto City and 4) Willing to be a participant in this study. While the exclusion criteria in this study are: 1) Having visual impairment, 2) Having hearing loss, 3) Students who cannot answer pre-test and post-test questions completely, and 4) Students / i who do not come to during the intervention. From the observations made, data were obtained for all 124 students of SMP Negeri 5 Mojokerto who were obese as many as 124 people. While there were 33 samples included in the inclusion and exclusion criteria.

\section{Ethical Consideration}

This research has received a permission from the ethics commission of Universitas Muhammadiyah Malang with a letter number (No.E.5.a/084/KEPK-UMM/III/2020)

\section{Measurement}

Measurements of body weight, height, abdominal circumference, and Body Mass Index (BMI) have been carried out by the respective puskesmas every one year and monitored by the School Health Unit (UKS) every month. The results of these data are used by the authors to conduct this research.

\section{E. Data Analysis}

Researchers use the help of computer software to conduct data analysis. Before conducting data analysis, firstly testing the requirements so that the conclusions drawn do not deviate from the truth needed is drawn. Test requirements are tests of normality. If the results of the requirements analysis are normally distributed, data analysis is performed to measure the level of knowledge using the paired t-test (paired t-test). However, if the data from the analysis results are not normally distributed, data analysis is performed to measure the level of knowledge using the Wilcoxon Matched-Pair Signed Rank Test. The type of data in the Wilcoxon Matched-Pair Signed Rank Test is the ordinal and numeric scale data or interval / ratio scale data provided that the data are not normally distributed. The results of calculations to answer statistical hypotheses.

\section{RESULTS AND DISCUSSION}

\section{A. Research Result}

\section{Characteristics of Respondents}

Participants who participated in this study were 124 students with details of grade 7 totaling 44 students, grade 8 totaling 46 students, and grade 9 totaling 34 students, which were then grouped into the inclusion and exclusion criteria that had been determined due to the sampling technique used in the study this is purposive sampling. Inclusion criteria in this study are: 1) Students who are categorized as obese, 2) Aged 15 years and above, 3) Take education in SMP Negeri 5 Mojokerto, 4) Willing to be a respondent. Furthermore, the exclusion criteria in this study are: 1) Having visual impairment, 2) Having hearing loss, 3) Students who cannot answer the pre-test and post-test questions completely, 4) Students / i who did not come when intervention. From the results of grouping respondents into inclusion and exclusion criteria, obtained samples included in the inclusion criteria were 33 people. 
Characteristics of respondents by gender and age can be known from the folowing table:

TABLE I. CHARACTERISTICS OF RESPONDENTS BY GENDER AND AGE

\begin{tabular}{|c|c|c|c|}
\hline \multicolumn{2}{|c|}{ Characteristics of Respondents } & Amount & Percentage \\
\hline \multirow{2}{*}{ Gender } & $\mathrm{L}$ & 13 & $39.4 \%$ \\
& $\mathrm{P}$ & 20 & $60.6 \%$ \\
\hline \multirow{2}{*}{ Age } & 15 & 31 & $93.9 \%$ \\
& 16 & 2 & $6.1 \%$ \\
\hline \multicolumn{2}{|c|}{ Total } & $\mathbf{3 3}$ & $\mathbf{1 0 0} \%$ \\
\hline
\end{tabular}

Based on the characteristics table of respondents according to gender and age (table 1) above, respondents with the most dominant female sex are $20(60.6 \%)$ respondents and the remaining $13(39.4 \%)$ respondents are male. Furthermore there were $31(93.9 \%)$ respondents who were 15 years old and 2 $(6.1 \%)$ respondents who were 16 years old. From the table above, both of these ages fall into the adolescent age category and meet the specified inclusion inclusion criteria.

\section{Pre-Test and Post-Test Score Data}

The frequency distribution of knowledge pre-test scores regarding the prevention of diabetes mellitus can be found from the following table:

TABLE II. FREQUENCY DISTRIBUTION OF PRE-TEST AND POSTTEST SCORES

\begin{tabular}{|l|c|c|c|c|}
\hline \multirow{2}{*}{ Category } & \multicolumn{2}{|c|}{ Pre-Test } & \multicolumn{2}{c|}{ Post-Test } \\
\cline { 2 - 5 } & Amount & Percentage & Amount & Percentage \\
\hline $\begin{array}{l}\text { Good } \\
\text { Knowledge }\end{array}$ & 0 & $0.0 \%$ & 26 & $78.8 \%$ \\
\hline $\begin{array}{l}\text { Sufficient } \\
\text { Knowledge }\end{array}$ & 4 & $12.1 \%$ & 4 & $12.1 \%$ \\
\hline $\begin{array}{l}\text { Lack of } \\
\text { Knowledge }\end{array}$ & 29 & $87.9 \%$ & 3 & $9.1 \%$ \\
\hline \multicolumn{1}{c|}{ Total } & $\mathbf{3 3}$ & $\mathbf{1 0 0 \%}$ & $\mathbf{3 3}$ & $\mathbf{1 0 0 \%}$ \\
\hline
\end{tabular}

Before the treatment is given, researchers first pre-test respondents. The number of question points given in the posttest is 20 question points. Research subjects in this pre-test totaled 33 people. According to Budiman \& Agus, the level of knowledge is categorized into 3 groups based on percentage acquisition. Students can be categorized as having a good level of knowledge if the percentage value of students is between $75 \%-100 \%$, having a level of knowledge is sufficient if the percentage value of students is between $56 \%-74 \%$, and having a level of knowledge is less if the percentage value of students is between $0 \%-55 \% .{ }^{14}$ Based on the table of frequency distribution of pre-test and post-test scores (table 2) above, there were $4(12.1 \%)$ respondents with sufficient level of knowledge and 29 (87.9\%) respondents with less knowledge level. Then after being given treatment using song and brochure media, the authors conducted a post-test to respondents. The results of this post-test are used as a benchmark to increase knowledge after being given treatment. Based on the table of frequency distribution of pre-test and post-test scores (table 2) above, respondents with the most dominant level of good knowledge were 26 (78.8\%) respondents, then there were $4(12.1 \%)$ participants with sufficient level of knowledge and $3(9.1 \%)$ participants with less knowledge.

\section{Bivariate Analysis}

Before conducting the analysis, the data must be normally distributed first. Therefore, a prerequisite test is carried out, namely the analysis of the normality of the data distribution test. The results of the data distribution normality test are:

Normality test data distribution Pre-test and Post-test Knowledge

The results of the normality test score of the pre-test variable knowledge, obtained a significance value of 0.209 . When compared with $\alpha=0.05$, the significance value $(0.209>$ $0.05)$. Thus it can be said that the data is normally distributed. While the results of the normality test post-test knowledge score, the results obtained significance value of 0.005 . When compared with $\alpha=0.05$, the significance value is smaller $(0.005<0.05)$. Thus it can be said that the data is not normally distributed. Test results can be seen in the following table:

\section{TABLE III. TEST NORMALITY OF KNOWLEDGE PRE-TEST AND} POST-TEST DATA DISTRIBUTION TESTS OF NORMALITY

\begin{tabular}{|l|c|c|c|}
\hline \multirow{2}{*}{ Test of Normality } & \multicolumn{3}{|c|}{ Shapiro-Wilk } \\
\cline { 2 - 4 } & Statistic & Df & Sig. \\
\hline Pretest Results & .957 & 33 & .209 \\
\hline Posttest Results & .899 & 33 & .005 \\
\hline
\end{tabular}

\section{Hypothesis Test}

After conducting univariate analysis, the next step is to conduct a bivariate test. Researchers use the help of computer software to carry out this analysis. To test the effectiveness of song and brochure media on increasing adolescent knowledge in efforts to prevent diabetes mellitus early on. The data analysis technique used in this study is the Wilcoxon MatchedPair Signed Rank Test because there is one data that is not normally distributed.

TABLE IV. COMPARISON OF DATA ANAYSIS EVELS OF KNOWLEDGE

\begin{tabular}{|l|l|c|c|c|}
\hline \multicolumn{2}{|c|}{ Ranks } & N & $\begin{array}{c}\text { Mean } \\
\text { Rank }\end{array}$ & $\begin{array}{c}\text { Sum of } \\
\text { Ranks }\end{array}$ \\
\hline Posttest Value & Negative Ranks & $0^{\mathrm{a}}$ & .00 & .00 \\
Categories - & Positive Ranks & $29^{\mathrm{b}}$ & 15.00 & 435.00 \\
Pretest Value & Ties & $4^{\mathrm{c}}$ & & \\
\cline { 2 - 5 } Categories & Total & 33 & & \\
\hline
\end{tabular}

a. Posttest Value Categories < Pretest Value Categories

b. Posttest Value Categories > Pretest Value Categories

c. Posttest Value Category $=$ Pretest Value Category

Based on the comparative data analysis table of the level of knowledge (table 3) above, it is known that there were no respondents whose knowledge results were lower than before being given song and brochure media, 4 people remained, and 29 people experienced an increase in knowledge after being given song and brochure media with an average rating of 15 , 00 and the total rating of 435.00 . 
TABLE V. ANALYSIS RESULTS OF THE WILCOXON MATCHEDPAIR SIGNED RANK TEST

\begin{tabular}{|l|c|}
\hline \multicolumn{1}{|c|}{ Test Statistics } & \multicolumn{1}{c|}{$\begin{array}{c}\text { Posttest Value Categories - } \\
\text { Pretest Value Categories }\end{array}$} \\
\hline Asymp. Sig. (2-tailed) & .000 \\
\hline
\end{tabular}

Based on the analysis table of the matched-pair wilcoxon signed rank test test (table 4) above, the results of the analysis using the matched-pair wilcoxon test signed rank test obtained a significance value of $0,000(p<0.05)$ which states that there are significant differences in knowledge adolescents in their efforts to prevent diabetes mellitus between before and after given song and brochure media.

\section{B. Discussion of Research Results}

Before being treated using song and brochure media, participants are first given a pre-test of knowledge about the prevention of diabetes mellitus. The number of question points given for pre-test and post-test is 20 questions. Pre-test aims to determine the level of initial knowledge about diabetes mellitus. After being given an intervention, a post-test is then conducted on the participants to find out whether there is an increase in knowledge regarding the prevention of diabetes mellitus. After being treated using song and brochure media, obtained from the data breakdown which states that found significant differences in adolescent knowledge in efforts to prevent diabetes mellitus between before and after being given song and brochure media.

Song and brochure media is a combination of media that can enhance one's knowledge. A study on the effectiveness of instructional media using song media to enhance knowledge that has been done by Wardhani \& Budiono who agreed that what was obtained from the $p$ value was 0,000 based on the results of the pre-test and post-test descriptions in the research group. After conducting the experiments, the results obtained were $\mathrm{p}$ values $<0.05$ which showed a significant difference from the pre-test and post-test in the testing group. These results prove that the educational song media about nutrition in this study is effective in increasing knowledge about the consumption of vegetables and fruits in children of SDN Pleburan 03, Semarang City. ${ }^{15}$ The results of Rickard et al. Regarding the benefits of classroom-based instrumental music programs on the verbal memory of elementary school children: a longitudinal study also discusses students who received intensive music training programs to promote better learning. ${ }^{16}$ conducted by Barus, et al. The research results prove that DM media about 2 in the Outpatient Polyclinic at Deli Serdang Hospital $(\mathrm{p}=0.002)$. This is because the media containing printed leaflets can be taken anywhere by people with type 2 diabetes can be placed at home as a reminder to make a healthy lifestyle. While the flip sheet media can only be used when counseling or learning is carried out only on patients with type 2 DM can't consider what has been given through counseling using flip sheet media. ${ }^{17}$

In addition to increasing knowledge in a person, song and brochure media have benefits for the development of the human brain in the learning process. This relates to songs that are able to attract attention and are able to stimulate brain development, the rhythm of the song is easily accepted by students so that it is more fun and can increase the power to improve the material discussed will be stored in the memory of students. ${ }^{18}$ linking several areas in the brain that are related to one's memory and transition. ${ }^{19}$ Music can also increase the intelligence of one's brain because the stimulus from music makes neurons that do not participate, will discuss and contribute to circulation in the brain and form a fusion of right brain neurons with left brain neurons. Not only that, music can provide a greater amount of stimulation for the growth of factors that have emotional and cognitive intelligence. ${ }^{20}$ Music can stimulate and encourage participants to achieve goals in language, motor, and social activities. The media portraying music in school can change the atmosphere of student learning into fun. ${ }^{19}$ In the Great Book About Music, Al-Farabi who is one of the scientists from the east explains that music makes a sense of comfort and study, music can also be used as a moral education, a medium for controlling logic, restoring psychosomatic, and developing spiritually. ${ }^{21} \mathrm{~A}$ study of the benefits of music was also discussed by Linnemann et al. in a study entitled Listening to music as a means of reducing stress in everyday life. Express revealed that listening to music was effective in reducing subjective stress levels $(\mathrm{p}=0.010)$. The most easily found effect was 'relaxation' which was included as a reason for listening to music, with a reduction in subjective stress levels $(p \leq 0.001)$ and lower cortisol concentrations $(p \leq$ $0.001)$. Alpha-amylase varies according to the function of the selected musical stimulus, with music that has increased energy and relaxed music reduces alpha-amylase activity $(\mathrm{p}=0.025)$. This finding discusses music that discusses how to create stress in everyday life, especially if there is a discussion about the reasons for relaxation. In addition, the results explain the physiological underlying effects of stress from music. ${ }^{22}$

Providing information formally or informally can increase knowledge. In addition to song media, the media provider is one of the informal information providers that is often used in the world of health. This is because the stimulus provided by the brochure is easily accepted by students. Media brochures can be obtained easily, can be read repeatedly, compiled, distributed, and effectively used as media information. As a medium of information, images or photos are selected or used according to the intended purpose. The picture or photo will arouse the participants' interest in interpreting and remembering the message conveyed. Brochures are more effectively distributed at school because brochures are media that can be read repeatedly, are easy to carry, and are economical. The existence of repetition in reading a brochure can increase the intensity of the information delivered. ${ }^{23} \mathrm{~A}$ study of the benefits of the brochure has been explained by Wang, et al. in his research entitled Effects of an Intervention Brochure on Emergency Department Patients' Safe Alcohol Use and Knowledge that controlled trials were conducted comparing subjects who received an alcohol use intervention brochure and did not receive a brochure. The results obtained in one month include: 1) changes in alcohol drinking behavior every day, 2) changes in knowledge about safe alcohol use, and 3) changes in excessive alcohol use. Of the 277 subjects, $252(91.0 \%)$ agreed to participate, and $188(74.6 \%)$ were successfully contacted for follow-up assessments within a month. From the results of the follow-up, it was concluded that the brochure could influence 
the motivation of certain patients to change their alcohol drinking behavior. ${ }^{24}$

Intervention activities using song and brochure media is an active process where a person will get information and knowledge that can be used as a basis in the learning process. According to Arfan., Et al in research on the effectiveness of health education through e-file multimedia KRR material and face to face in the classroom on increasing adolescent reproductive health knowledge, participants who obtained information from the media had a higher increase in knowledge than participants who did not get information from the media . This is stated by the results of the coefficient value of 1.65 and the acquisition obtained from the $\mathrm{p}$ value is $0.000(\mathrm{p}>0.05)$ indicating that the media has an impact on the increase in respondents' knowledge. ${ }^{25}$

The addition of songs and brochures as a medium of health education can make students feel happy and enjoy the material being taught. The level of concentration, motivation and interest, and learning activities also increased because their psychological condition became better with the presence of song and brochure media. This is in line with MacDonald's research that song is seen as a pleasant means to explore themselves, improve mood, and create satisfying artistic products. This was evidenced by participants who reported changes in time perception. Time was considered to have moved quickly and participants felt that they "forgot time" and were disappointed when their session ended. ${ }^{26}$ In addition, Astuti also strengthened the existence of research on the effect of brochures on increasing student learning activities which stated the results of the study showed that the use of instructional materials could increase student learning activities with an average value of all aspects of the high-criteria experimental class $(75.53 \%)$ with the highest aspect presenting the results of group discussions $(88.3 \%)$ and the lowest aspect of expressing ideas $(66.3 \%)$. In addition, in general students $(74.16 \%)$ gave positive responses to the use of brochures. Astuti also explained that the increase in learning outcomes occurred because the brochure teaching materials were able to attract students' learning interest because of their attractive design and the material presented was concise and equipped with supporting images of the material. The interest in student learning makes it easier for students to learn the material presented. This is supported by the responses of students who mostly stated they were more pleased to learn the material presented through the brochure and easier to understand the material learned through the brochure. ${ }^{27}$

Therefore, song media can be done as an alternative in providing health education. Through this song media, students can gain knowledge about prevention of diabetes mellitus and how to change their healthy behavior. Arfan et al., Explained that health education is very important because education is the most basic tool for increasing adolescents' knowledge and abilities in maintaining themselves. ${ }^{17}$ With this increase in knowledge, participants will be able to apply healthy living behaviors, as stated by Notoatmodjo that knowledge is one cause that has an impact on individual actions. So the better the knowledge of individual health, the better the actions and behavior of a person towards health. ${ }^{22}$ Forming or changing behavior is not an easy thing, because in theory it must go through several stages. Before changing behavior, there is a cognitive element that begins knowledge. According to cognitive psychology theory, knowledge is obtained from learning outcomes and knowledge changes that result in behavioral changes. ${ }^{23}$ Low health knowledge is a predisposing factor of health behavior that causes illness. The higher the level of individual education, the better the attitude knowledge, and behavior to implement a healthy lifestyle. ${ }^{24}$

This study has independent variables consisting of song and brochure media and variables that contain adolescent knowledge in an effort to overcome diabetes mellitus. Therefore, no research was carried out on reducing the incidence of diabetes mellitus and obesity in SMP Negeri 5 Mojokerto. Other factors that cause diabetes mellitus such as excessive eating or unbalanced diet, lack of physical fitness and exercise, pregnancy, hypertension, dyslipidemia, and smoking are also not proven.

\section{CONCLUSION AND RECOMMENDATIONS}

Based on the results of data analysis and hypothesis testing that has been done shows that there are significant differences in adolescent knowledge in efforts to prevent diabetes mellitus between before and after being given song and brochure media. From the results of this analysis, it can be concluded that the use of song and brochure media is effective in increasing adolescent knowledge in efforts to prevent diabetes mellitus. This is because the song and brochure media contributes positively to the promotion of diabetes mellitus prevention. Nutrition education regarding the prevention of diabetes mellitus in adolescents is the main target that must be done, considering that adolescents are a multifactorial vulnerable age and one of the most sensitive groups to accept change or renewal. Nutrition education for adolescents should be provided with an attractive atmosphere. So, suggestions from researchers include: 1) It is expected that the relevant Health Office and Puskesmas conduct nutrition education regarding the prevention of diabetes mellitus by using song and brochure media because this media is easier to understand and understood by participants, 2) It is recommended to use nutrition education media as a combination or combination so that the nutrition education process can run better, and 3) There is a need for further research related to other types of nutrition education media. So that it can be seen the strengths and weaknesses of each nutrition education media, 4) The need for further research related to song media with other targets, 5) It is recommended to develop CERDIK jingle songs in detail.

\section{ACKNOWLEDGMENT}

The researchers thank to who participated in this study.

\section{REFERENCES}

[1] Kementerian Kesehatan Republik Indonesia, "Kenali Kebiasaan Penyebab Diabetes," Kementerian. Kesehatan. Republik Indonesia., pp. 1-2, 2015, [Online]. Available: www.kemkes.go.id.

[2] Kementerian Kesehatan Republik Indonesia, Infodatin Hari Diabetes Sedunia Tahun 2018. Jakarta Selatan: Pusdatin Kemenkes, 2019.

[3] Kementerian Kesehatan Republik Indonesia, Hasil Utama Riskesdas 2018. Jakarta: Kementerian Kesehatan Badan Penelitian dan Pengembangan Kesehatan, 2018. 
[4] Kementerian Kesehatan RI, Hasil Utama Riset Kesehatan Dasar Provinsi Jawa Timur 2018. Jakarta: Kementerian Kesehatan Republik Indonesia, 2018

[5] S. Yaturu, "Obesity and Type 2 Diabetes Mellitus," J. Diabetes Melllitus, vol. 1, no. 4, pp. 79-95, 2011, doi: 10.4236/jdm.2011.14012.

[6] W. Kurdanti et al., "Jurnal Gizi Klinik Indonesia Faktor-faktor yang mempengaruhi kejadian obesitas pada remaja," vol. 11, no. 04, pp 179-190, 2015, [Online]. Available: https://www.google.com/url?sa= $\mathrm{t} \& \mathrm{rct}=\mathrm{j} \& \mathrm{q}=\&$ esrc $=\mathrm{s} \&$ source $=$ web $\& \mathrm{~cd}=4 \& \mathrm{cad}=\mathrm{rja} \& u a c t=8 \& \mathrm{ved}=2 \mathrm{ahU}$ KEwjQzY2JyofmAhVGSX0KHQNUB4gQFjADegQICRAC\&url=http s\%3A\%2F\%2Fjurnal.ugm.ac.id\%2Fjgki\%2Farticle\%2Fdownload\%2F2 2900\%2F15594\&usg=AOvVaw0GYsEsevdSvlTTDYCiQIat.

[7] K. I. Wahyuni, A. A. Prayitno, and Y. I. Wibowo, "Efektivitas Edukasi Pasien Diabetes Mellitus Tipe 2 Terhadap Pengetahuan dan Kontrol Glikemik Rawat Jalan di RS Anwar Medika," J. Pharmascience, vol. 6 , no. 1, p. 1, 2019, doi: 10.20527/jps.v6i1.6069.

[8] R.. Widyoga, Saichudin, and O. Andiana, "Hubungan Tingka Pengetahuan tentang Penyakit Diabetes Melitus pada Penderita terhadap Pengaturan Pola Makan dan Physical Activity," Sport Science. Health., vol. 2, no. 2, pp. 152-161, 2020, [Online]. Available: http://jou rnal2.um.ac.id/index.php/jfik/index.

[9] R. Ismayanti, "Efektivitas Promosi Kesehatan Melalui Media Lagu Terhadap Pengetahuan Ibu Mengenai Gizi Seimbang di Paguyuban Wali Murid Kelompok Bermain Al-Ikhlas Pandanwangi - Kota Malang," Universitas Negeri Malang, 2017.

[10] L. I. Suciana, "Pengaruh Penggunaan Media Lagu Terhadap Kemampuan Menulis Cerpen Siswa Kelas X SMA Negeri 6 Kediri,' Universitas Nusantara PGRI Kediri, 2017.

[11] R. Ismayanti, M. Devi, and S. Katmawanti, "The Effectiveness Of Health Promotion Through Song Towards Mother's Knowledge On Balanced Nutrition In Kindergarten Student," vol. 7, no. Icssh 2018, pp. 164-168, 2019, doi: 10.2991/icssh-18.2019.38.

[12] D. B. Putra, "Efektivitas Media Promosi Kesehatan Leaflet Dan Brosur Pada Pasien Hipertensi," Universitas Jember, 2017.

[13] R. Stefanie, "Respon Pengunjung Terhadap Media," J. E-Komunikasi, vol. 1, no. 3, 2013, [Online]. Available: https://www.dropbox.com/s/m8 9v9idd710rihi/jpkomunikasidd130320.pdf?dl=0.

[14] B. \& A. Riyanto, Kapita Selekta Kuisioner Pengetahuan Dan Sikap Dalam Penelitian Kesehatan. Jakarta: Salemba Medika, 2013.

[15] R. P. S. Wardhani and I. Budiono, "Lagu Edukasi Gizi Lebih Efektif Meningkatkan Pengetahuan Sayur \& Buah Pada Siswi Perempuan," J. Heal. Educ., vol. 3, no. 2, 2018, [Online]. Available: http://journal.unne s.ac.id/sju/index.php/jhealthedu.

[16] N. S. Rickard, J. T. Vasquez, F. Murphy, A. Gill, and S. R. Toukhsati, "Benefits of a Classroom Based Instrumental Music Program On Verbal Memory Of Primary School Children: A Longitudinal Study," Aust. J. Music Education., vol. 1, no. 1, pp. 36-47, 2010, [Online]. Available: https://eric.ed.gov/?id=EJ912414.

[17] R. H. Barus, D. Nababan, and F. L. Tarigan, "Pengaruh Konseling Dengan Media Lembar Balik Dan Brosur Terhadap Pengetahuan Tentang Gaya Hidup Pada Pasien Dm Tipe 2 Di Poli Rawat Jalan RSUD Deli Serdang," J. Muara Sains, Teknologi. Kedokteran. dan Ilmu Kesehatan., vol. 3, no. 2, p. 259, 2020, doi: 10.24912/jmstkik.v3i2 .5425 .
[18] A. M. Nggiri, "Keefektifan Penggunaan Media Lagu Terhadap Penguasaan Kosakata Bahasa Jerman Peserta Didik Kelas X SMA Negeri 1 Muntilan Magelang," Universitas Negeri Yogyakarta, 2014.

[19] I. F. Wulandini, "Pengaruh Media Ilustrasi Musik Terhadap Kemampuan Menulis Puisi Siswa Kelas X (Eksperimen di SMA PGRI 22 Serpong)," Universitas Islam Negeri (UIN) Syarif Hidayatullah Jakarta, 2011.

[20] A. Roffiq, I. Qiram, and G. Rubiono, "Media Musik dan Lagu pada Proses Pembelajaran," J. Pendidik. Dasar Indonesia., vol. 2, no. 2, pp. 35-40, 2017, [Online]. Available: https://r.search.yahoo.com/ ylt=Awr x5ZY2osNe0hYAPGf3RQx.;_ylu=X3oDMTByYmpmZjA4BGNvbG8 Dc2czBHBvcwMzBHZ0aWQDBHNlYwNzcg--/RV=2/RE=158990815 0/RO=10/RU=https\%3A\%2F\%2Fjournal.stkipsingkawang.ac.id\%2Find ex.php\%2FJPDI\%2Farticle\%2Fview\%2F330/RK=2/RS=n21u9aY7yuz AHC.

[21] F. A. Susanti, Devi W. dan Rohmah, "Efektivitas Musik Klasik dalam Menurunkan Kecemasan Matematika (Math Anxiety) pada Siswa Kelas XI,” Humanit. Indones. Psychol. J., vol. 8, no. 2, pp. 130-142, 2011 [Online]. Available: http://www.academia.edu/download/40524096/per an-religious-coping-sebagai-moderator-dari-job-insecurity-terhadap-str es-kerja-pada-staf-akademik.pdf.

[22] A. Linnemann, B. Ditzen, J. Strahler, J. M. Doerr, and U. M. Nater, "Music listening as a means of stress reduction in daily life," Psychoneuroendocrinology, vol. 60. pp. 82-90, 2015, doi: 10.1016/j.ps yneuen.2015.06.008.

[23] S. Notoatmodjo, Metodologi Penelitian Kesehatan. Jakarta: Rineka Cipta, 2010.

[24] T. C. Wang, D. N. Kyriacou, and M. S. Wolf, "Effects of an Intervention Brochure On Emergency Department Patients' Safe Alcohol Use And Knowledge," J. Emergency. Medical., vol. 39, no. 5 , pp. 561-568, 2010, doi: 10.1016/j.jemermed.2008.03.003.

[25] M. Arfan, S. A. Wilopo, and B. Wahyuni, "Efektivitas Pendidikan Kesehatan Melalui E- File Multimedia Materi KRR Dan Tatap Muka Di Kelas Terhadap Peningkatan Pengetahuan Kesehatan Reproduksi Remaja," Ber. Kedokt. Masy., vol. 26, no. 3, pp. 107-114, 2010, doi: 10 1109/WAINA.2013.176.

[26] R. A. R. MacDonald, "Music, health, and well-being: A review," Int. J. Qual. Stud. Health Well-being, vol. 8, no. 1, 2013, doi: 10.3402/qhw.v8 i0.20635.

[27] E. F. Astuti, "Pengaruh Penggunaan Bahan Ajar Brosur Terhadap Aktivitas dan Penguasaan Materi Oleh Siswa," Universitas Lampung, 2014.

[28] S. Notoatmodjo, Promosi Kesehatan dan Perilaku Kesehatan. Jakarta: Rineka Cipta, 2012.

[29] N. M. S. Wulanyani, "Meningkatkan Pengetahuan Kesehatan melalui Permainan Ular Tangga," J. Psikol., vol. 40, no. 2, pp. 181-192, 2014 , doi: 10.22146/jpsi.6976.

[30] A. Ramadhan, Cholil, and B. I. Sukmana, "Hubungan Tingkat Pengetahuan Kesehatan Gigi dan Mulut Terhadap Angka Karies Gigi di SMPN 1 Marabaha," Kedokt. Gigi, vol. 1, no. 2, pp. 66-69, 2016, [Online]. Available: https://ppjp.ulm.ac.id/journal/index.php/dentino/art icle/view/567. 